\title{
Delineation of a Fundamental $\alpha$-Ketoheterocycle Substituent Effect For Use in the Design of Enzyme Inhibitors
}

\author{
F. Anthony Romero, Inkyu Hwang, and Dale L. Boger ${ }^{\star}$ \\ Department of Chemistry and the Skaggs Institute for Chemical Biology, The Scripps Research \\ Institute, 10550 North Torrey Pines Road, La Jolla, California 92037
}

Anandamide $^{1}(\mathbf{1 a})$ and oleamide ${ }^{2-4}(\mathbf{1 b})$ have emerged as the prototypical members of a class of endogenous fatty acid amides that serve as chemical messengers (Figure 1). Anandamide binds and activates the central (CB1) and peripheral (CB2) cannabinoid receptors where it has been implicated in the modulation of nociception, feeding and anxiety. ${ }^{5}$ Oleamide was found to accumulate in the cerebrospinal fluid of animals under conditions of sleep deprivation and induces physiological sleep in a dose dependent manner. ${ }^{3,4}$ The pharmacological action of both anandamide and oleamide is terminated by the enzyme fatty acid amide hydrolase (FAAH; Figure 1) ${ }^{6-9}$ It degrades neuromodulating fatty acid amides at their site of action and is currently the only characterized mammalian enzyme that is in the amidase signature family bearing an unusual catalytic Ser-Ser-Lys triad. ${ }^{6-9}$ As such, FAAH has emerged as an exciting therapeutic target for a range of clinical disorders. 5,10

One class of FAAH inhibitors that exhibit potent and selective enzyme inhibition and in vivo efficacy is the $\alpha$-ketoheterocycles. ${ }^{11-16}$

Since their introduction by Edwards, ${ }^{17-19}$ the use of such $\alpha$-ketoheterocycles has emerged as a powerful design concept for the development of inhibitors of serine and cysteine proteases and hydrolases. ${ }^{20}$ Possessing electrophilic carbonyls, they reversibly form enzyme-stabilized covalent hemiketals or hemithioketals with the enzyme catalytic nucleophile analogous to more conventional aldehyde, ${ }^{21}$ trifluoromethyl ketone, ${ }^{22}$ or $\alpha$-keto ester ${ }^{23}$ and amide inhibitors. 24 By virtue of the ability of the heterocycle to hydrogen-bond to the adjacent hemiketal of the enzyme adduct ${ }^{17-19}$ and because of interactions of the heterocycle itself with the enzyme active site independent of its role in activating the carbonyl, ${ }^{13}$ they offer advantages over the simpler predecessors. Although the potency of such $\alpha$-ketoheterocycles has been anticipated to be related to the intrinsic electron-withdrawing properties of the heterocycles, ${ }^{17-19}$ attempts to draw such correlations are weak, accompanied by deviations from expectations, and the more potent heterocycles in a series are empirically derived. 25

Herein, we report the synthesis and evaluation of a series of 5-substituted 7-phenyl-1(oxazol-2-yl)heptan-1-ones that define an alternative and fundamental $\alpha$-ketoheterocycle substituent effect that led to the discovery of FAAH inhibitors with $K_{\mathrm{i}}$ 's as low as $400 \mathrm{pM}$. Its intrinsic basis, which relates $K_{\mathrm{i}}$ with the Hammett $\sigma_{\mathrm{p}}$ constant of the substituent, as well as the magnitude of the effect $(\rho=3.01)$, and its predictive value $\left(R^{2}=0.91\right)$ suggest a widespread applicability in studies beyond FAAH inhibition.

E-mail: boger@scripps.edu.

Supporting Information Available: Full experimental details and characterization, and FAAH assay measurement errors of the inhibitors disclosed herein. This information is available free of charge via the Internet at http://pubs.acs.org. 
Key to the divergent synthesis of the inhibitors was the preparation of intermediate $\mathbf{3}$ from which all the compounds could be derived (Scheme 1). Intermediate 3 was obtained by Vedejs oxazole metalation, ${ }^{26}$ condensation with 7-phenylheptanal and TBS protection of the resulting alcohol. Selective $\mathrm{C} 5$-lithiation 27 of $\mathbf{3}$ followed by treatment with various electrophiles $\left(\mathrm{CO}_{2}(\mathrm{~g}), \mathrm{CF}_{3} \mathrm{CONMe}_{2}, \mathrm{CH}_{3} \mathrm{CONMe}_{2}\right.$, DMF, $\mathrm{I}_{2}, \mathrm{Br}_{2}, \mathrm{NCS}, \mathrm{N}$-fluorobenzenesulfonimide, $\left.\mathrm{CH}_{3} \mathrm{I},(\mathrm{MeS})_{2}\right)$ afforded $\mathbf{4 b}, \mathbf{4 f}-\mathbf{h}, \mathbf{4} \mathbf{j}$ and $\mathbf{4 l}-\mathbf{p}$, many of which served as precursors to additional candidate inhibitors bearing further modified $\mathbf{C} 5$-substituents. Carboxylic acid $\mathbf{5 b}$ was directly converted to its corresponding methyl ester $\mathbf{5 c}$ by treatment with $\mathrm{TMSCHN}_{2}$. The ester $\mathbf{5 c}$ was converted to the carboxamide $\mathbf{5 d}$ by treatment with methanolic ammonia, which, in turn, was dehydrated with TFAA and pyridine to provide nitrile $5 \mathbf{i}$. Using a method developed by Chen et al., iodide $4 \mathbf{l}$ was transformed to $4 \mathbf{k}\left(\mathrm{FSO}_{2} \mathrm{CF}_{2} \mathrm{CO}_{2} \mathrm{CH}_{3}\right.$, $\left.\mathrm{CuI}\right)$ bearing a $\mathrm{C} 5$ trifluoromethyl substituent. ${ }^{28,29}$ In each case, deprotection of the TBS ether followed by Dess-Martin periodinane oxidation ${ }^{30}$ of the liberated alcohol yielded the corresponding $\alpha$-ketoheterocycles.

This series, which constitutes a set of relatively small substituents that can occupy accessible space in the FAAH active site, exhibited FAAH inhibition that tracked with the electronwithdrawing properties of the substituents (Figure 2). A plot of the inhibition $\left(-\log K_{\mathrm{i}}\right)$ versus the Hammett $\sigma_{\mathrm{p}}$ constant for the substituents (Figure 3) was found to follow a well-defined correlation $\left(\rho=3.01, R^{2}=0.91\right)$. In addition, this substituent effect was established to be large $(\rho=3.01)$ resulting in a 1000-fold increase in $K_{\mathrm{i}}$ per unit change in $\sigma_{\mathrm{p}}$ and indicating that the electronic character of the substituent is the dominant factor contributing to the differences in binding affinity. Presumably, this arises from the increased electrophilic character of the $\mathrm{C} 2$ carbonyl imparted by the electron-withdrawing $\mathrm{C} 5$ substituent that leads to an increased strength of the covalent bond formed with the catalytic Ser241 OH thereby enhancing the stability of the tetrahedral adduct and lowering the $K_{\mathrm{i}}$ value. ${ }^{31}$ The definition of this fundamental relationship between the $K_{\mathrm{i}}$ and substituent property $\left(\sigma_{\mathrm{p}}\right)$ permits the prediction of an expected $K_{\mathrm{i}}$. For example, we can assert that the carboxylic acid $\mathbf{5 b}$ binds FAAH as the carboxylate anion $\left(-\mathrm{CO}_{2}{ }^{-}\right.$vs $-\mathrm{CO}_{2} \mathrm{H}, \sigma_{\mathrm{p}}=0.11$ vs 0.44$)$ under the conditions of the assay (from the $K_{\mathrm{i}}$ value, $\mathrm{pH} 9$ ). Even more interestingly, we are able to establish that both the aldehyde $\mathbf{5 g}$ and trifluoromethyl ketone $\mathbf{5 h}$ exist in solution as gem diols (at $\mathrm{C} 5$, but not $\mathrm{C} 2 ;{ }^{1} \mathrm{H}$ and ${ }^{13} \mathrm{C}$ NMR $)$ and inhibit the enzyme with potencies $\left(K_{\mathrm{i}}=6\right.$ and $\left.3.5 \mathrm{nM}\right)$ at a level more consistent with this $\mathrm{C} 5$ substituent gem diol versus carbonyl active site binding and providing the first $\sigma_{\mathrm{p}}$ estimates for such substituents $\left(0.26\right.$ for $\mathrm{CH}(\mathrm{OH})_{2}$ and 0.33 for $\mathrm{C}$ $\left.(\mathrm{OH})_{2} \mathrm{CF}_{3}\right) .{ }^{32}$ That is, the correlation between $\sigma_{\mathrm{p}}$ and $K_{\mathrm{i}}$ is sufficiently dependable that deviations from expectations can be utilized to establish features of active site binding that are not a priori known. Similarly, with this correlation in hand, two of the more potent inhibitors in Figure $2(\mathbf{5 f}, \mathbf{5 g})$ were retrospectively prepared and examined based on this relationship. Notably, 5c, 5i, and $\mathbf{5 k}$ bearing the strongest electron-withdrawing substituents, display subnanomolar FAAH inhibitory potency. While additional substituent features can and will further modulate the binding affinity of the candidate inhibitors (e.g., H-bonding, hydrophobic or steric interactions), ${ }^{33}$ the magnitude of the electronic effect of the substituent $(\rho=3.01)$ on the activity of a conjugated $\alpha$-ketoheterocycle $\left(K_{\mathrm{i}}\right)$ suggest the latter will dominate, especially with small and simple substitutents.

The delineation of a fundamental correlation that relates the Hammett $\sigma_{\mathrm{p}}$ constant of a substituent with its enzyme inhibition $\left(-\log K_{\mathrm{i}}\right)$ and the magnitude of the effect $(\rho=3.01)$ provides a useful new predictive tool for the rational design of serine and cysteine protease and hydrolase inhibitors.

\section{Supplementary Material}

Refer to Web version on PubMed Central for supplementary material. 


\section{Acknowledgment}

We gratefully acknowledge the financial support of the National Institutes of Health (DA15648) and the Skaggs Institute for Chemical Biology, and the postdoctoral fellowship support for F.A.R. (American Cancer Society).

\section{References}

1. Dervane WA, Hanus L, Breuer A, Pertwee RG, Stevenson LA, Griffin G, Gibson D, Mandelbaum A, Etinger A, Mechoulam R. Science 1992;258:1946. [PubMed: 1470919]

2. Boger DL, Henriksen SJ, Cravatt BF. Curr. Pharm. Des 1998;4:303. [PubMed: 10197045]

3. Cravatt BF, Lerner RA, Boger DL. J. Am. Chem. Soc 1996;118:580.

4. Cravatt BF, Prospero-Garcia O, Suizdak G, Gilula NB, Henriksen SJ, Boger DL, Lerner RA. Science 1995;268:1506. [PubMed: 7770779]

5. Lambert DM, Fowler CJ. J. Med. Chem 2005;48:5059. [PubMed: 16078824]

6. Bracey MH, Hanson MA, Masuda KR, Stevens RC, Cravatt BF. Science 2002;298:1793. [PubMed: 12459591]

7. Cravatt BF, Giang DK, Mayfield SP, Boger DL, Lerner RA, Gilula NB. Nature 1996;384:83. [PubMed: 8900284]

8. Giang DK, Cravatt BF. Proc. Natl. Acad. Sci. U.S.A 1997;94:2238. [PubMed: 9122178]

9. Boger DL, Fecik RA, Patterson JE, Miyauchi H, Patricelli MP, Cravatt BF. Bioorg. Med. Chem. Lett 2000;10:2613. [PubMed: 11128635]

10. Cravatt BF, Lichtman AH. Curr. Opin. Chem. Biol 2003;7:469. [PubMed: 12941421]

11. Boger DL, Miyauchi H, Du W, Hardouin C, Fecik RA, Cheng H, Hwang I, Hedrick MP, Leung D, Acevedo O, Guimaráes CRW, Jorgensen WL, Cravatt BF. J. Med. Chem 2005;48:1849. [PubMed: 15771430]

12. Boger DL, Miyauchi H, Hedrick MP. Bioorg. Med. Chem. Lett 2001;11:1517. [PubMed: 11412972]

13. Boger DL, Sato H, Lerner AE, Hedrick MP, Fecik RA, Miyauchi H, Wilkie GD, Austin BJ, Patricelli MP, Cravatt BF. Proc. Natl. Acad. Sci. U.S.A 2000;97:5044. [PubMed: 10805767]

14. Du W, Hardouin C, Cheng H, Hwang I, Boger DL. Bioorg. Med. Chem. Lett 2005;15:103. [PubMed: 15582420]

15. Leung D, Du W, Hardouin C, Cheng H, Hwang I, Cravatt BF, Boger DL. Bioorg. Med. Chem. Lett 2005;15:1423. [PubMed: 15713400]

16. Lichtman AH, Leung D, Shelton CC, Saghatelian A, Hardouin C, Boger DL, Cravatt BF. J. Pharmacol. Exp. Ther 2004;311:441. [PubMed: 15229230]

17. Edwards PD, Meyer EF, Vijayalakshmi J, Tuthill PA, Andisik DA, Gomes B, Strimpler A. J. Am. Chem. Soc 1992;114:1854.

18. Edwards PD, Zottola MA, Davis M, Williams CM, Tuthill PA. J. Med. Chem 1995;38:3972. [PubMed: 7562931]

19. Edwards PD, Zottola MA, Davis M, Williams J, Tuthill PA. J. Med. Chem 1995;38:76. [PubMed: 7837243]

20. Costanzo MJ, Almond HR, Hecker LR, Schott MR, Yabut SC, Zhang H-C, Andrade-Gordon P, Corcoran TW, Giardino EC, Kauffman JA, Lewis JM, de Garavilla L, Haertlein BJ, Maryanoff BE. J. Med. Chem 2005;48:1984. [PubMed: 15771442]

21. Westerik JO, Wolfenden R. J. Biol. Chem 1972;247:8195. [PubMed: 4640942]

22. Wolfenden R. Annu. Rev. Biophys. Bioeng 1976;5:271. [PubMed: 7991]

23. Angelastro MR, Mehdi S, Burkhart JP, Peet NP, Bey P. J. Med. Chem 1990;33:11. [PubMed: 2296008]

24. Ocain TD, Rich DH. J. Med. Chem 1992;35:451. [PubMed: 1738140]

25. Ohmoto K, Yamamoto T, Okuma M, Horiuchi T, Imanishi H, Odagaki Y, Kawabata K, Sekioka T, Hirota Y, Matsuoka S, Nakai H, Toda M. J. Med. Chem 2001;44:1268. [PubMed: 11312926]

26. Vedejs E, Monahan SD. J. Org. Chem 1996;61:5192.

27. Hari Y, Obika S, Sakaki M, Morio K, Yamagata Y, Imanishi T. Tetrahedron 2002;58:3051.

28. Chen Q-Y, Wu S-W. J. Chem. Soc., Chem. Commun 1989:705. 
29. Qing F-L, Fan J, Sun H-B, Yue X-J. J. Chem. Soc., Perkin Trans 1997;1:3053.

30. Dess DB, Martin JC. J. Am. Chem. Soc 1991;113:7277.

31. A reviewer has suggested that this may also arise from an increased H-bond capability of the oxazole nitrogen known to stabilize such enzyme adducts.

32. An anomalous $\sigma_{\mathrm{p}}$ of 0.22 is occasionally reported for $-\mathrm{CHO}$ (vs 0.42 ) that may more accurately reflect the analogous, but unrecognized gem diol.

33. An example is provided in Supporting Information. 

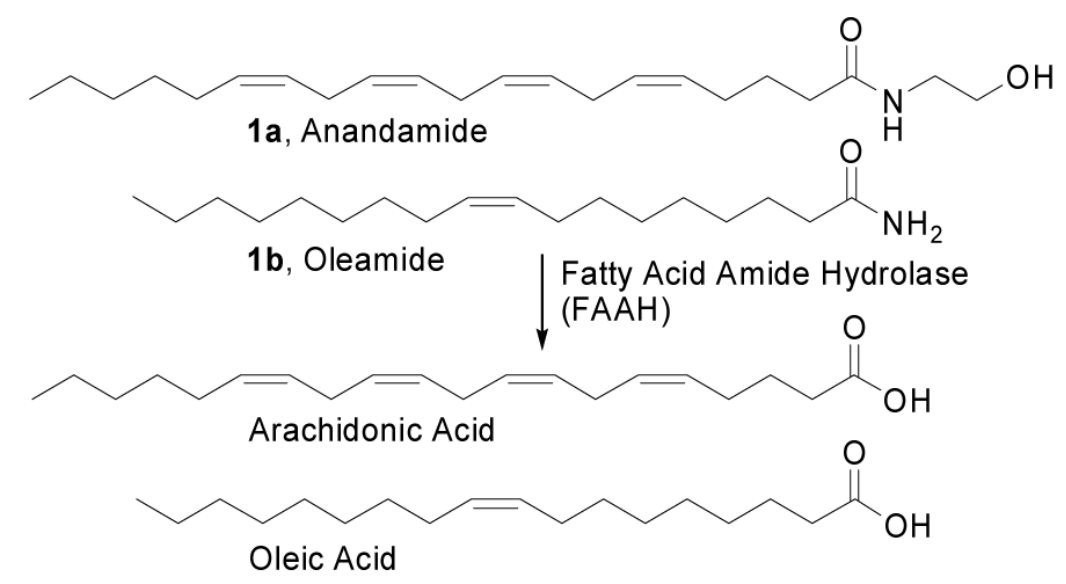

Figure 1.

Substrates of fatty acid amide hydrolase (FAAH). 


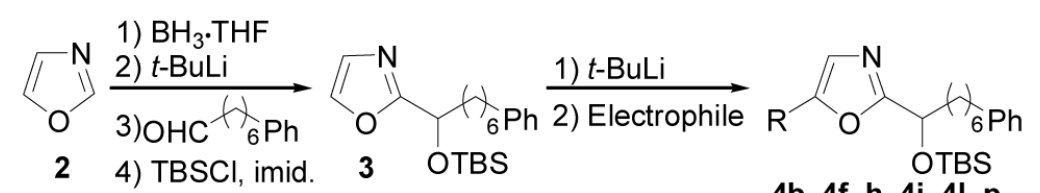

2 4) TBSCl, imid. 3 OTBS

4b, 4f-h, 4j, 4I-p

$\mathrm{R}=\mathrm{CO}_{2} \mathrm{H}, \mathrm{CH}_{3} \mathrm{CO}, \mathrm{CHO}, \mathrm{CF}_{3} \mathrm{CO}$, $\mathrm{I}, \mathrm{Br}, \mathrm{Cl}, \mathrm{F}, \mathrm{Me}, \mathrm{SCH}_{3}$
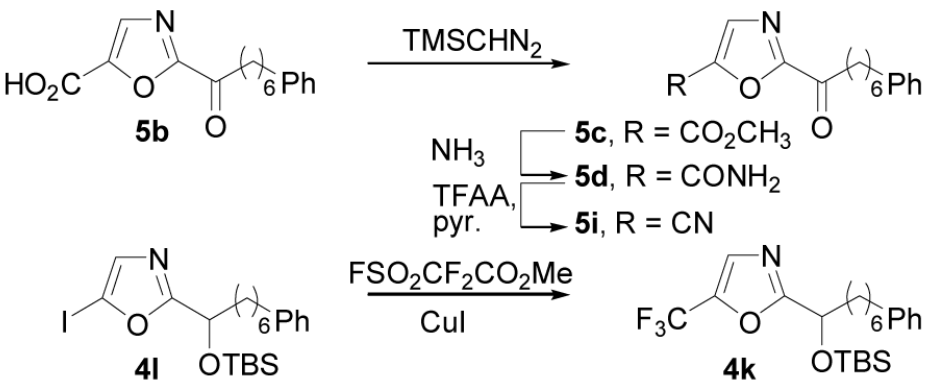

Scheme 1. 


\begin{tabular}{|c|c|c|c|c|c|}
\hline compd & $\mathrm{R}$ & $K_{\mathrm{i}}, \mathrm{nM}^{\mathrm{a}}$ & compd & $\mathrm{R}$ & $K_{\mathrm{i}}, \mathrm{nM}^{\mathrm{a}}$ \\
\hline $5 a$ & $-\mathrm{H}$ & 48 & $5 \mathbf{i}$ & $-\mathrm{CN}$ & 0.4 \\
\hline $5 b$ & $-\mathrm{CO}_{2} \mathrm{H}$ & 30 & $5 j$ & $-\mathrm{CH}_{3}$ & 80 \\
\hline $5 c$ & $-\mathrm{CO}_{2} \mathrm{CH}_{3}$ & 0.9 & $5 k$ & $-\mathrm{CF}_{3}$ & 0.8 \\
\hline $5 d$ & $-\mathrm{CONH}_{2}$ & 5 & 51 & -1 & 3 \\
\hline $5 e$ & $-\mathrm{CONMe}_{2}$ & 2 & $5 \mathrm{~m}$ & $-\mathrm{Br}$ & 3 \\
\hline $5 f$ & $-\mathrm{COCH}_{3}$ & 2 & $5 n$ & $-\mathrm{Cl}$ & 5 \\
\hline $5 \mathrm{~g}$ & $-\mathrm{CHO}$ & 6 & 50 & $-F$ & 30 \\
\hline $5 \mathrm{~h}$ & $-\mathrm{CF}_{3} \mathrm{CO}$ & 3.5 & $5 p$ & $-\mathrm{SCH}_{3}$ & 25 \\
\hline
\end{tabular}

Figure 2.

FAAH inhibition. ${ }^{a}$ Measurement errors are provided in Supporting Information. 


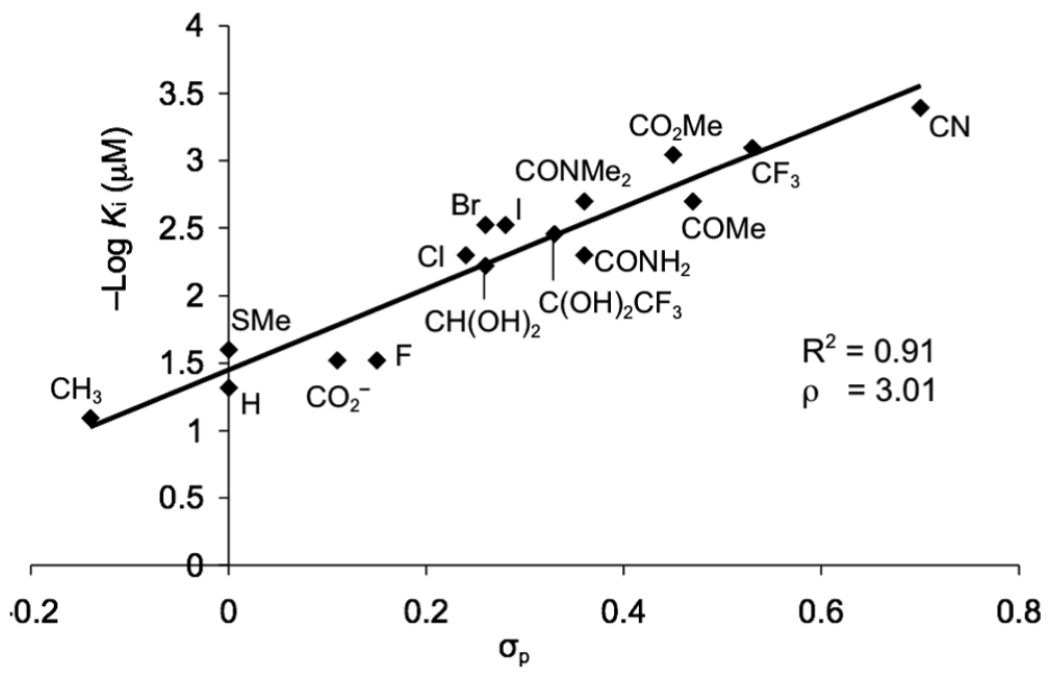

Figure 3.

$-\log K_{\mathrm{i}}(\mu \mathrm{M})$ versus $\sigma_{\mathrm{p}}$. 


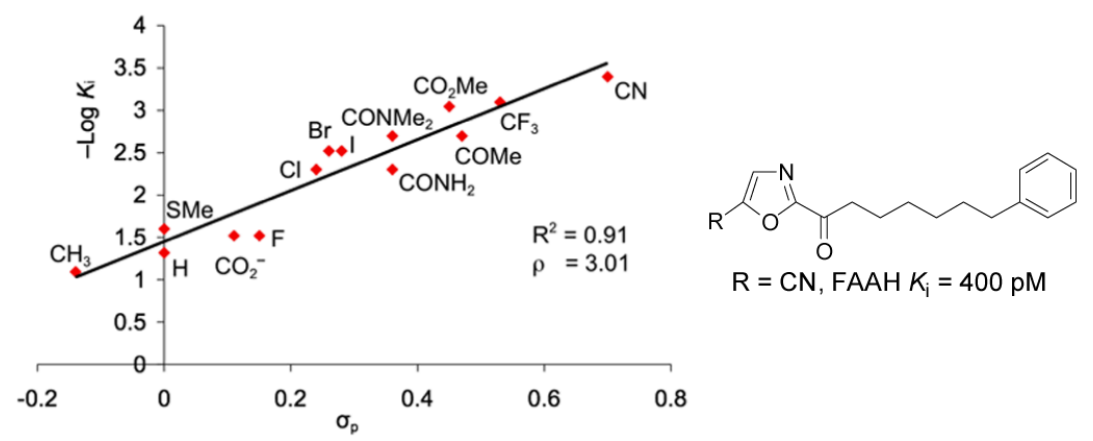

The synthesis and examination of a systematic series of 5-substituted 2-keto oxazoles as inhibitors of fatty acid amide hydrolase (FAAH) defined a fundamental substituent effect that led to the discovery of inhibitors with $K_{\mathrm{i}}$ 's as low as $400 \mathrm{pM}$. The intrinsic basis of the relationship ( $-\log K_{\mathrm{i}}$ vs $\sigma_{\mathrm{p}}$ ), which relates $K_{\mathrm{i}}$ with the Hammett $\sigma_{\mathrm{p}}$ constant of the substituent, the magnitude of the effect $(\rho=3.01)$, and its predictive value $\left(R^{2}=0.91\right)$ suggest a widespread applicability in studies beyond FAAH. 